\title{
PENINGKATAN KINERJA GURU DALAM MENGEMBANGKAN INDIKATOR PENCAPAIAN KOMPETENSI MATA PELAJARAN AGAMA HINDU DAN BUDHI PEKERTI MELALUI PELATIHAN BERKELANJUTAN DI SD BINAAN KECAMATAN SUSUT KABUPATEN BANGLI TAHUN 2018
}

\author{
Oleh : \\ Ida Ayu Wulansari \\ Kantor Kementerian Agama Kabupaten Bangli \\ idaayuwulansari@gmail.com
}

Diterima 11 Oktober 2018, direvisi 6 Pebruari 2019, diterbitkan 29 Maret 2019

\begin{abstract}
The purpose of this study is to improve the performance of Hindu religious teachers at Binaan elementary schools in Susut district, in Bangli regency. This study was a Regional School Action Research (PTSW) which using three cycles design and each cycle consists of four stages, namely: planning, action, gathering, and reflection. In order to obtain the data, this study used assessment techniques consist of tests of teacher ability to develop indicators of achievement of competency. It was starting by observations, development, achievement of competencies. This study was quantitative presented in the form of descriptive narratives. The results of this study shows that, the teacher's performance can be improved in developing indicators competency of Hinduism and Buddhism. Furthermore, from 16 teachers who thoroughly examined the results of each cycle with an increase in the original value of the first cycle was $66.56 \%$ then, in cycle 2 increased to $71.25 \%$, and in the third cycle increased to $85.63 \%$. However, based on the result of the analysis, supervision guidance through effective training is implemented in an effort to improve the teacher performance.
\end{abstract}

Keywords: The improvement of teacher performance in developing competence achievement indicators for the study of Hindu religion and budhi pekerti through sustainable training in binaan elementary school in susut district,

\section{PENDAHULUAN}

Guru profesional sesuai dengan jabatan profesinya, semestinya memiliki berbagai kompetensi yang dipersyaratkan dan selalu dikembangkan searah dengan perkembangan serta regulasi pendidikan yang berlaku dalam perubahan Kurikulum 2013 tahun 2018. Kurang aktifnya guru dalam mengembangkan diri melalui pembiasaan budaya baca untuk meningkatkan diri dalam memahami peraturan di bidang pendidikan mengisyaratkan pada pengawas untuk melakukan tindakan pelatihan berkelanjutan agar tidak jauh dari buku, kebiasaan diskusi, menulis serta melakukan penelitian. Pembenahan dan peningkatan mutu guru berkaitan dengan kompetensi profesional harus dilakukan sepanjang kariernya.

Menghadapi paradigma baru bagi guru yang sarat dengan berbagai perkembangan dan perubahan regulasi pendidikan menjadi beban bagi guru untuk terus ditingkatkan atau dikembangkan kompetensinya. Pengawas sebagai mitra kerja guru wajib membina dan melatih secara berkelanjutan pada guru mulai dari perencanaan pembelajaran, pelaksanaan 
proses pembelajaran, penilaian proses pembelajaran dan menganalisis serta menindaklanjuti hasil analisis.

Sekolah Dasar binaan di wilayah kecamatan Susut sebanyak 30 sekolah, dengan jumlah Guru Agama Hindu yang dibina sebanyak 57 orang. Penerapan Kurikulum 2013 dimulai dari 5 SD terlebih dahulu yang ditunjuk sebagai pilot project pelaksana Kurikulum 2013 pada tahun ajaran 2016/2017. Selanjutnya pada tahun ajaran 2017/2018, pelaksana Kurikulum 2013 ditambah dengan sekolah imbas lagi 12 SD, sehingga sekolah pelaksana Kurikulum 2013 di kecamatan Susut berjumlah 17 SD.

Penerapan Kurikulum 2013 telah diawali dengan kegiatan Sosialisasi bagi Sekolah Pelaksana Kurikulum 2013 dan dilanjutkan Bimbingan Teknis Administrasi Perangkat Pembelajaran Kurikulum 2013. Dari 57 orangGuru Agama Hindu, yang telah mengikuti kegiatan tersebut adalah 30 orang. Ternyata guru yang memiliki kemampuan mempersiapkan perencanaan pembelajaran sesuai hasil Bimtek baru 14 orang dan sisanya lagi 16 belum sesuai dengan standar. Berdasarkan hal tersebut maka Pengawas melakukan terobosan untuk melakukan pelatihan dan pembinaan secara berkelanjutan melalui kegiatan KKG di wilayah binaan.

Pembinaan yang dilakukan oleh Pengawas terutama yang berkaitan dengan adminsitrasi guru yang meliputi : Program tahunan, program semester, pengembangan silabus dan administrasi perangkat pembelajaran lainnya, serta RPP yang dimulai dari penyusunan Indikator Pencapaian Kompetensi.

Dari 16 orang Guru yang belum bisa membuat administrasi pembelajaran sesuai dengan pedoman, 4 Guru dalam pelaksanaan tugas mengajar berdasarkan pada materi ajar yang termuat dalam buku paket, sedangkan 10 orang lainnya melaksanakan tugas tanpa melakukan persiapan perencanaan pembelajaran dengan baik.

Indikator pencapaian kompetensi yang semestinya digunakan sebagai pijakan awal bagi guru dalam pengembangan perencanaan pembelajaran, namun pada kenyataannnya guru belum memiliki kemampuan dalam menyusun indikator pencapaian kompetensi diakibatkan belum memahami secara utuh tentang peran dari indikator pencapaian kompetensi dalam perencanaan pembelajaran.

Berdasarkan hasil wawancara dengan 16 guru, dalam membuat perencanaan pembelajaran guru sangat sulit dalam menentukan pemilihan kata kerja operasional taksonomi Anderson dalam tiga ranah, ranah pengetahuan dari C1 sampai C6, ranah afektif A1 sampi A5, ranah psykomotor P1 sampai $\mathrm{P} 4$, dimana kata kunci penggunaan kata kerja operasional bertumpu pada kata kunci Kompetensi Dasar masing-masing Kompetensi Inti.

Kurangnya pemahaman yang baik dalam mengembangkan indikator pencapaian kompetensi dari tiap-tiap kompetensi dasar dalam mata pelajaran yang diampunya, hal ini berpengaruh terhadap kualitas perencanaan pembelajaran dan selanjutnya mempengaruhi kualitas pelaksanaan pembelajaran, evaluasi dan rencana tindak lanjutnya.

Oleh karena itu peran Pengawas dalam membina guru melalui pelatihan berkelanjutan sangat penting terutama dalam perencanaan pembelajaran yang berawal dari penyusunan indikator pencapaian kompetensi sebagai sentral pembelajaran.

Dari uraian tersebut di atas, maka masalah dalam penelitian ini dapat diidentifikasi sebagai berikut :

1. Rendahnya kinerja guru agama dalam mengembangkan indikator pencapaian kompetensi mata pelajaran Agama Hindu dan Budhi Pekerti.

2. Rendahnya daya serap guru dalam bimbingan teknis yang diberikan Pengawas kepada guru untuk meningkatkan kinerja guru.

3. Rendahnya respon guru terhadap pembinaan yang diberikan Pengawas.

4. Kurang mampu mengimplementasikan model 
pembinaan yang diberikan Pengawas dalam meningkatkan kinerja guru.

5. Rendahnya kemampuan guru dalam menyusun indikator pencapaian kompetensi

6. Kurangnya pemahaman guru dalam menentukan kata kerja operasional tiga ranah kognitif, afektif dan psikomotor.

Begitu banyaknya permasalahan yang dihadapi guru namun yang paling mendasar menjadi pokok permasalahan untuk diteliti adalah rendahnya kinerja guru agama dalam mengembangkan indikator pencapaian kompetensi mata pelajaran Agama Hindu dan Budhi Pekerti. Proses pembelajaran akan berjalan efektif dan menyenangkan jika perencanaan dari persiapan mengajar memenuhi standar proses mulai dari pengembangan Indikator Pencapaian Kompetensi. Tujuan kegiatan ini adalah untuk meningkatkan kinerja guru dalam pengembangan indikator pencapaian kompetensi mata pelajaran Agama Hindu dan Budhi Pekerti melalui pelatihan berkelanjutan di SD Binaan Kecamatan Susut Kabupaten Bangli Tahun pelajaran 2018.

Manfaat Penelitian adalah berguna untuk meningkatkan mutu pendidikan agama Hindu SD di Kecamatan Susut Kabupaten Bangli. Bagi guru unuk meningkatkan kualitas kemampuan guru dalam penyusunan indikator pencapaian kompetensi sebagai bahan perencanaan pembelajaran.

Bagi siswa, mengaktifkan peserta didik untuk memahami materi pembelajaran yang telah disiapkan secara matang berawal dari pengemabangan indicator pencapaian kompetensi sesuai kebutuhannya.

Istilah kinerja dapat diterjemahkan dalam perfomance atau unjuk kerja, artinya kemampuan yang ditampilkan seseorang terhadap pekerjaannya pada tempat ia bekerja. Kinerja merupakan suatu kinerja yang esensial terhadap keberhasilan suatu pekerjaan. Karena itu suatu kinerja yang efektif bagi setiap individu perlu diciptakan sehingga tujuan lembaga dapat tercapai secara optimal.

Menurut Fattah (1996) kinerja diartikan sebagai ungkapan kemajuan yang didasari oleh pengetahuan, sikap, keterampilan dan motivasi dalam menghasilkan suatu pekerjaan. Dengan demikian dapat disimpulkan bahwa kinerja adalah hasil kerja seseorang yang mencerminkan prestasi kerja sebagai ungkapan pengetahuan, sikap dan keterampilan.

Menurut Supriadi (1998) kinerja guru akan menjadi lebih baik, bila seorang guru memiliki lima hal yakni:

1. Mempunyai komitmen pada siswa dan proses belajarnya

2. Menguasai secara mendalam bahan mata pelajaran yang akan diajarkan serta cara mengajarnya kepada siswa

3. Bertanggung jawab memantau hasil belajar siswa melalui berbagai cara evaluasi dan

4. Guru mampu berpikir sistematis tentang apa yang dilakukannya dan belajar serta pengalamannya.

Lebih lanjut Hamalik (2002) kemampuan dasar yang disebut juga kinerja dari seorang guru terdiri dari: (1) kemampuan merencanakan pembelajaran, (2) kemampuan mengelola program belajar mengajar, (3) kemampuan menglola kelas (4) kemampuan menggunakan media/sumber belajar, (5) kemampuan menglola interaksi belajar mengajar, (6) mampu melaksanakan evaluasi belajar siswa.

Kinerja guru sangat terkait dengan efektifitas guru dalam melaksanakan fungsinya oleh Medley dalam Depdikbud (1984) dijelaskan bahwa efektifitas guru yaitu: (1) memiliki pribadi kooperatif, daya tarik, penampilan amat besar, pertimbangan dan kepemimpinan, (2) menguasai metode mengajar yang baik, (3) memiliki tingkah laku yang baik saat mengajar, dan (4) menguasai berbagai kompetensi dalam mengajar.

Pengembangan IPK harus mengakomodasi kompetensi yang tercantum 
dalam KD. IPK dirumuskan dalam bentuk kalimat dengan kata kerja operasional. Rumusan IPK sekurang-kurangnya mencakup dua hal yaitu tingkat kompetensi dan materi yang menjadi media pencapaian kompetensi. Kata kerja operasional pada IPK pencapaian kompetensi aspek pengetahuan mengacu pada ranah kognitif taksonomi Bloom, aspek sikap mengacu pada ranah afektif Krthwl, sedangkan aspek ketrampilan mengacu pada ranah psikomotor Dyers.

IPK pada Kurikulum 2013 untuk KD yang diturunkan dari KI-1 dan KI-2 dirumuskan dalam bentuk perilaku umum yang bermuatan nilai dan sikap yang gejalanya dapat diamati sebagai dampak pengiring dari KD pada KI-3 dan KI-4. IPK untuk KD yang diturunkan dari KI-3 dan KI-4 dirumuskan dalam bentuk spesifik yang dapat diamati dan diukur.

Cara-cara perumusan Indikator Pencapaian Kompetensi adalah sebagai berikut :

a. Indikator dirumuskan dari KD dengan memahami kata kunci KD;

b. Menggunakan kata kerja operasional yang dapat diukur;

c. Dirumuskan dengan kalimat yang simpel,jelas dan mudah dipahami;

d. Tidak menggunakan kata yang bermakna ganda dan hanya mengandung satu tindakan;

e. Tetap memperhatikan karakteristik matapelajaran, potensi dan kebutuhan peserta didik, sekolah, masyarakat dan lingkungan/daerah.

Proses penulisan IPK diawali dengan $\mathrm{KD}$ ranah pengetahuan yang digabungkan melalui KKO pengetahuan. Selanjutnya KD ranah ketrampilan dirangkai dengan KKO ketrampilan. Berikutnya KD ranah sikap spiritual dirangkai dengan KKO sikap spiritual, dan KD ranah sikap sosial dengan KKO sikap sosial. Dari kata kunci KD akan lahir IPK setelah dirangkai dengan KKO disesuaikan dengan pembagian waktu efektif pertemuan masing-masing KD. Kata kunci KD dengan IPK pengetahuan dan ketrampilan akan menentukan metode, strategi dan pendekatan pembelajaran, yang selanjutnya akan tercermin pada hasil pembelajaran melalui penilaian.

Konsep pengembangan profesi berkelanjutan sebagaimana dinyatakan dalam penelitian yang berjudul Pengembangan Profesi Guru secara Berkelanjutan adalah pengembangan kompetensi guru yang dilaksanakan sesuai dengan kebutuhan, bertahap, berkelanjutan untuk meningkatkan profesionalitasnya. Jenis kegiatan pengembangan keprofesian berkelanjutan meliputi pengembangan diri melalui diklat fungsional dapat berupa kursus, pelatihan, penataran, bentuk diklat yang lain (Sukanti: $2016: 2$ ).

Dyah Lyesmaya dalam Jurnalnya menyatakan bahwa penyelenggaraan program pengembangan profesi berkelanjutan merupakan upaya dalam meningkatkan profesinalisme guru agar memiliki kompetensi sesuai dengan peraturan perundang-undangan serta perkembangan ilmu pengetahuan, teknologi, dan/atau seni. Pelaksanaan program ini diatur melalui Permenag PAN dan RB nomor 16 tahun 2009 pasal 11 ayat c, bahwa "komponen pengembangan keprofesian berkelanjutan terdiri dari tiga hal yaitu : pengembangan diri (terdiri dari diklat fungsional, dan kegiatan kolektif guru); publikasi imliah ( presentasi pad gagasan dibidang pendidikan formal, dan publikasi buku pelajaran, pengayaan dan pedoman guru) dan karya inovatif (menemukan teknologi tepat guna, menemukan/menciptakan karya seni, membuat/memodifikasi alat pelajaran/peraga/praktikum, dan mengikuti pengembangan penyusunan standar, pedoman, soal dan sejenisnya ".

Dengan demikian pelatihan berkelanjutan bagi guru yang dilaksanakan dengan tujuan untuk meningkatkan ketrampilan dan pengetahuan para guru dalam melaksanakan peran dan fungsinya, serta untuk memecahkan permasalahan yang dihadapi oleh guru di 
kelas, dalam melaksanakan tugas-tugas seperti program pengajaran, pembinaan sarana dan fasilitas sekolah, serta pembinaan hubungan kerja sama antara masyarakat dengan sekolah dapat tercapai dan mutu pendidikan dapat ditingkatkan.

\section{Metodologi Penelitian}

Metode wawancara digunakan dalam penelitian untuk tujuan tertentu, agar mendapat keterangan atau pendirian secara lisan dari respondent, dengan bercakap-cakap atau bertatap muka langsung kepada orang yang diwawancarai itu (Koentjakraningrat, 1977:162). Wawancara sebagai metode dipergunakan untuk mendapatkan data-data, keterangan-keterangan, pendirian-pendirian mengenai pokok masalah supaya hasil yang didapatkan mencakup keseluruhan. Mengenai wawancara mendalam dilakukan terhadap informan tertentu, yakni wawancara kepada orang-orang yang dianggap tahu dan menguasai permasalahan yang sedang diteliti. Untuk mengarahkan pembicaraan pada pokok permasalahan dipergunakan pedoman wawancara.

Indikator keberhasilan jika dari kondisi awal setelah dilaksanakan pelatihan berkelanjuta pada 16 guru yang memiliki kemauan dan aktif saat pelaksanaan pelatihan diharapkan guru yang memiliki kreatifitas dan inovasi dalam perumusan Indikator Pencapaian Kompetensi mata pelajaran Agama Hindu.

Penelitian Tindakan Sekolah Wilayah yang dilaksanakan dalam tiga siklus dianggap sudah berhasil apabila terjadi Peningkatan Kinerja guru dalam mengembangkan indikator pencapaian kompetensi mata pelajaran Agama Hindu dan Budhi Pekerti mencapai $85 \%$ dari guru yang diteliti, .Jika peningkatan tersebut dapat dicapai pada tahap siklus 1 dan 2 , maka siklus selanjutnya tidak akan dilaksanakan karena penelitian tindakan yang dilakukan sudah dinilai efektif. Penskoran penilaian dari hasil test kemampuan menyusun indikator pencapaian kompetensi dinyatakan tuntas jika memperoleh nilai minimal 70 .

Skor perolehan penilaian ditentukan dengan predikat :

$\mathrm{A}=$ sangat baik dengan rentang nilai 91 100

$\mathrm{B}=$ baik dengan rentang nilai $81-90$

$\mathrm{C}=$ cukup dengan rentang nilai $71-80$

$\mathrm{D}=$ kurang baik untuk nilai $\leq 70$

\section{HASIL DAN PEMBAHASAN}

Hasil setiap siklus dalam penelitian ini senantiasa mengalami peningkatan walaupun belum semuanya memenuhi kreteria ketuntasan minimal dengan predikat baik. Setelah dilakukan tindakan kepengawasan pada siklus 1, siklus 2 dan siklus 3 menunjukkan hasil sebagai berikut.

1. Pencapaian Peningkatan kinerja guru sebelum sebelum diberi tindakan

$$
=\frac{1065}{1600} \times 100 \%=66,56 \%
$$

2. Peningkatan Kinerja guru dalam mengembangkan indikator pencapaian kompetensi mata pelajaran Agama Hindu dan Budhi Pekerti setelah diberi tindakan melalui pola pelatihan berkelanjutan.

$$
=\frac{1140}{1600} \times 100 \%=71,25 \%
$$

3. Peningkatan Kinerja guru dalam mengembangkan indikator pencapaian kompetensi mata pelajaran Agama Hindu dan Budhi Pekerti setelah diberi tindakan.

$$
=\frac{1370}{1600} \times 100 \%=85,63 \%
$$

Dari hasil analisis tersebut dapat disimpulkan bahwa

a. Terjadi peningkatan kinerja guru setelah diberi pembinaan melalui pelatihan berkelanjutan yaitu Peningkatan Kinerja guru dalam mengembangkan indikator pencapaian kompetensi mata pelajaran Agama Hindu dan Budhi Pekerti ; 66,56 $\%$ menjadi $71,25 \%$ ada kenaikan sebesar $=4,69 \%$ 
b. Dari sebelum pembinaan (siklus 1) dan setelah pembinaan oleh Pengawas sampai dengan (siklus 2) 66,56\% menjadi $71,25 \%$, dan siklus ke 3 juga mengalami kenaikan dari 71,25\% menjadi $85,63 \%$, naik $14,38 \%$.

\section{KESIMPULAN}

Berdasarkan analisis hasil penelitian dan diskusi dapat disimpulkan sebagai berikut :

1. Pembinaan peningkatan kinerja guru melalui pelatihan berkelanjutan dapat meningkatkan kompetensi guru dalam mengembangkan indikator pencapaian kompetensi mata pelajaran Agama Hindu dan Budhi Pekerti dengan capaian setiap siklus mengalami peningkatan dari $66,56 \%$ menjadi $71,25 \%$ dan meningkat menjadi $85,63 \%$.

2. Pelatihan berkelanjutan perlu terus dilaksanakan dalam meningkatkan kinerja guru mengantisipasi segala bentuk perubahan peraturan dibidang pendidikan sehingga guru dapat meningkatkan kinerja secara inovatif, kreatif dan mandiri.

3. Aktivitas guru menunjukan bahwa kegiatan pembinaan melalui penerapan pelatihan berkelanjutan bermanfaat dan dapat membantu guru untuk lebih mudah memahami pengunaan KKO sesuai dengan kata kunci KD sehingga peningkatan kinerja guru dalam mengembangkan indikator pencapaian kompetensi mata pelajaran Agama Hindu dan Budhi Pekerti sesuai standar Permendikbud nomor 22 tahun 2016 tentang Standar Proses.

4.

\section{SARAN}

1. Kepada guru agar senantiasa meningkatkan profesionalitas melalui berbagai kegiatan dalam bentuk pelatihan berkelanjutan, workshop, bimtek serta semakin sering diskusi dengan teman sejawat.
2. Kepada Pengawas agar senantiasa meningkatkan pengamatan dan pembimbingan pada guru wilayah binaan dan mencarikan alternatif solusi sebagai tindak lanjut analisis hasil kepengawasan sesuai dengan kebutuhan guru.

3. Kepada lembaga terkait $\mathrm{KKG}, \mathrm{KKKS}$, UPT Disdikpora agar senantiasa memfasilitasi dalam keaktifan organisasi profesi Pengawas dan Guru dengan dukungan sarana prasarana yang memadai untuk menunjang peningkatan kualitas pendidikan.

\section{DAFTAR PUSTAKA}

Arbi, S. Z. dan Syahrun, S. 1992. DasarDasar Kependidikan. Jakarta: Departemen Pendidikan dan Kebudayaan, Direktorat Jenderal Pendidikan Tinggi

Arifin, I. 2000. Profesionalisme Guru: Analisis Wacana Reformsi Pendidikan dam Era Globalisasi. Simposium Nasional Pendidikan di Universitas Muhammadiyah Malang, 25-26 Juli 2001.

Arikunto, Suharsini. 2004. Dasar - dasar Supervisi. Jakarta: Rineka Cipta. 2007.Penelitian Tindakan Kelas.Jakarta : PT Bumi Aksara.

Atmodiwiro, Soebagio dan Soenarto Tatosiswanto, 1991. Kepemimpinan Pengawas, Semarang: Adhi Waskitho. Bafadal Ibrahim, 1979. Supervisi Pengajaran Teori dan Aplikasinya dalam Membina Profesional Guru, Jakarta: Rineka Cipta.

Dedi Herawan, 2005. Pengembangan Model Supervisi Akademik Mata Pelajaran IPA-Biologi: Efektifitas Model Inovasi Supervisi Akademik Mata Pelajaran IPA Biologi dalam Upaya Meningkatkan Kinerja Guru IPA Biologi di SMU. Tesis Tidak diterbitkan UPI Bandung. 
Depdiknas RI 2007, Peraturan No 12 Tentang

Kompetensi Pengawas.Jakarta :

Depdiknas

2007, Peraturan Menteri No

13 Tentang Kompetensi

Pengawas.Jakarta : Depdiknas. 2007, Peraturan Menteri No

19 Tentang Standar Pengelolaan Sekolah/Madrasah.Jakarta : Depdiknas

Dirjen PMPTK.2009. Bahan Belajar Mandiri Musyawarah kerja Pengawas Dimensi Supervisi.Jakarta : Dirjen PMPTK.

Departemen Pendidikan Nasional. 2006.

Undang-Undang Nomor 14 Tahun 2005

tentang Guru dan Dosen. Jakarta: Departemen Pendidikan Nasional

Ibrahim, R dan Karyadi, B. 1990. Materi Pokok: Pengembangan Inovasi dan

Kurikulum: Modul 1-6; Jakarta: Departemen Pendidikan dan Kebudayaan, Proyek Penataran Guru Setara D-II. 